\title{
ANALISIS PUTUSAN HAKIM DALAM TINDAK PIDANA PEMBUNUHAN BERENCANA (PUTUSAN NOMOR 1474/PID.B/2019/PN.DPS)
}

\author{
Dedi Romadhan, Anak Agung Sagung Laksmi Dewi, I Made Minggu Widyantara \\ Fakultas Ilmu Hukum Universitas Warmadewa, Denpasar - Bali, Indonesia \\ dedi.ramadhan502@gmail.com, laksmiidewi29@gmail.com, mademinggu21@gmail.com
}

\begin{abstract}
Abstrak
Terkadang dalam perkara yang memiliki tingkat kerumitan pembuktian yang tidak mudah, terjadi kesalahan hakim dalam pembuktian kesalahan terdakwa. Seperti putusan nomor 1474/Pid.B/2019/PN.Dps. Diasumsikan bahwa adan kesalahan hakim dalam menerapkan hukuman terhadap terdakwa. Tjuan penelitian ini adalah mengungkap bagaimanakah pengaturan hukum tentang tindak pidana pembunuhan berencana dan bagaimana pertimbangan hakim dalam menjatuhkan sanksi pidana terhadap pelaku tindak pidana pembunuhan berencana studi kasus Putusan Nomor 1474/Pid.B/2019/PN.Dps. Metode yang digunakan adalah penelitian hukum normatif. Hasil penelitian ini menunjukan bahwa pengaturan tentang pembunuhan berencana diatur dalam pasal 340 kitab undang-undang hukum pidana. Selain itu, pertimbangan hakim dalam menjatuhkan sanksi pidana terhadap pelaku tindak pidana pembunuhan berencana pada putusan nomor 1474/Pid.B/2019.PN.DPS yaitu majelis hakim dalam menjatuhkan putusan terhadap terdakwa berdasarkan fakta yang terungkap di persidangan, keterangan dari saksi-saksi, keterangan dari terdakwa serta dihubungkan visum et repertum dan barang-barang bukti yang ada diajukan di dalam persidangan. Pemerintah khususnya lembaga yudikatif disarankan mengawasi, membina proses peradilan dalam menerapkan hukuman.
\end{abstract}

Kata Kunci: Pembunuhan, Putusan Hakim, Tindak Pidana.

\begin{abstract}
Sometimes in cases that have a difficulty level of evidence, there is an error by the judge in proving the guilt of the defendant. Such as decision number 1474 / Pid.B / 2019 / PN.Dps. It is assumed that there was an error by the judge in applying the sentence to the defendant. The purpose of this research was to reveal how the legal arrangements regarding the crime of premeditated murder and how judges consider imposing criminal sanctions on perpetrators of premeditated murder in the case study of Decision Number 1474 / Pid.B / 2019 / PN.Dps. The method used was normative legal research. The results of this study indicated that the regulation of premeditated murder is regulated in Article 340 of the criminal codebook. In addition, the judge's consideration in imposing criminal sanctions on perpetrators of premeditated murder in decision number 1474 I Pid.B / 2019.PN.DPS, namely the panel of judges in ruling against the defendant based on facts revealed at trial, testimony from witnesses, the statement from the defendant and related visum et repertum, and existing evidence items submitted at trial. The government, especially the judiciary, is advised to supervise and foster the judicial process in implementing penalties.
\end{abstract}

Keywords: Murder, Judge's Decision, Crime

\section{PENDAHULUAN}

Negara Indonesia merupakan negara hukum, negara hukum lahir menjadi gagasan dalam perjuangan hak asasi manusia (Ekatjahjana, 2015). Hak asasi manusia merupakan hak yang melekat dalam diri manusia yang bersifat kodrati. Oleh karena itu, negara harus hadir untuk menghormati dan melindungi. Sebagai negara hukum maka di samping adanya perlindungan hak asasi manusia, juga adanya proses peradilan yang tidak memihak untuk mengatur persamaan setiap orang di hadapan hukum, serta menjamin keadilan bagi setiap orang terhadap penyalahgunaan wewenang pihak yang berkuasa (Sardol, 2014). Salah satu penerapan dalam negara hukum yaitu dalam aturan yang berkepastian, bersifat mengikat untuk mencapai keadilan dan perlindungan salah satunya melalui hukum pidana (Sagama, 2016).

Hakim adalah pejabat yang memimpin jalannya persidangan, yaitu kekuasaan yang merdeka buat menyelenggarakan peradilan guna menegakkan aturan dan keadilan. Pada dasarnya tugas hakim yaitu untuk membuat sebuah keputusan pada setiap kasus yang tiba kepadanya, menetapkan hal-hal 
yang meliputi hubungan hukum antara para pihak, nilai hukum dari perilaku, serta kedudukan hukum pihak-pihak yang terlibat dalam suatu kasus (Adonara, 2015). Sebagai akibat buat bisa menuntaskan perselisihan secara imparsial dari aturan yang berlaku, maka hakim dalam memutuskan setiap perkara tidak boleh terpengaruh oleh pihak manapun dan harus mandiri serta bebas dalam mengambil keputusannya.

Terkadang dalam kasus-kasus tertentu yang mempunyai taraf kerumitan pembuktian yang tidak mudah, terjadi kesalahan atau ketidak tepatan yang dilakukan oleh hakim dalam hal pembuktian kesalahan terdakwa (Ante, 2013; Nugroho, 2017). Misalnya dalam kasus pembunuhan berencana. Fakta-fakta di persidangan tidak menunjukkan bahwa suatu pembunuhan dilakukan dengan berencana, tetapi hakim dalam diputusnya menyatakan sebagai pembunuhan berencana. Adapun sebaliknya, kasus pembunuhan berencana diputuskan oleh hakim bukan sebagai pembunuhan berencana sekalipun di persidangan menampilkan bahwa sebenarnya pembunuhan dilakukan dengan berencana.

Putusan Pengadilan Negeri Denpasar Nomor 1474/Pid.B/2019/PN Dps sudah dirangkum sehingga menghasilkan kasus posisi sebagai berikut, berawal dari terdakwa menemukan perbincangan Halima yang merupakan istri siri Rudianto (terdakwa) dengan orang bernama Wawan di Facebook. Rudianto mengira halimah (korban) selingkuh dengan Wawan dan timbul niat Rudianto ingin membunuh Wawan selingkuhan istrinya karena Wawan menyebabkan rusaknya pernikahan terdakwa dengan Halimah. Kemudian terdakwa membeli dan mempersiapkan pisau di pasar kembang Surabaya Jawa Timur yang dimodifikasi seperti mata tombak di kedua sisinya tajam untuk digunakan dalam mempersiapkan untuk membunuh Wawan. Setelah itu terdakwa berangkat mengendarai motor dari Surabaya menuju Bali untuk bertemu dengan Halimah. Setelah ketemu korban halimah (istrinya) Terdakwa menanyakan "di mana kosnya?" dijawab oleh korban Halima "Mana uangnya?" Kemudian Terdakwa mengambil dompet dan dompet tersebut langsung ditarik dan diambil dari tangan Terdakwa oleh korban Halima. Kemudian uang dalam dompet diambil sebanyak Rp.1.700.000,- Kemudian dompet dikembalikan ke Terdakwa, dan kemudian halima (korban) berkata "sudahlah kamu pulang jangan urusin saya". setelah itu Rudianto mengatakan "jangan begitu kamu, saya cuman tanya dimana tempat kos kamu sekarang, kalau sudah punya suami bilang terus terang" dijawab oleh korban Halima "suami suami matamu", dan terdakwa menunjukan percakapan istrinya dengan selingkuhannya (Wawan). terdakwa menanyakan dimana wawan, namun korban Halima diam saja tidak menjawab pertanyaannya terdakwa, tetapi Halima malah emosi menyuruh terdakwa dengan berkata "sudah pulang kamu enggak usah ngurus saya" istrinya (korban) menjawab dengan perkataan tidak baik, kemudian terjadi percakapan antara terdakwa dan korban yang menjadi pemicu emosi terdakwa. Terdakwa langsung mengambil pisau di bawah jok sepeda motor yang sebenarnya mau digunakan untuk membunuh Wawan, kemudian terdakwa menusukkannya berkali-kali ke dada, perut dan punggung Halimah hingga meninggal dunia dan terakhir menendang kepala korban.

Penuntut umum mendakwa perbuatan terdakwa dengan dakwaan alternatif dengan menempatkan Pasal 340 KUHP sebagai dakwaan pertama atau Pasal 338 KUHP sebagai dakwaan kedua atau Pasal 351 (3) dakwaan ketiga. Setelah menjalani proses pembuktian di persidangan. Majelis hakim memutus terdakwa Rudianto bersalah melanggar pasal 340 KUHP dan dijatuhi hukuman penjara selama 16 tahun.

Menurut Memorie van Toelichting sebagaimana dikutip dalam Chazawi (2013) unsur rencana pada Pasal 340 KUHP memiliki karakteristik sebagai berikut.

1. Memutuskan kehendak pada suasana tenang.

2. Tersedia waktu yang cukup sejak timbulnya kehendak sampai dengan pelaksanaan kehendak.

3. Pelaksanaan kehendak dalam suasana tenang.

Penjelasan pertama menetapkan kehendak pada suasana tenang adalah pada saat memutuskan kehendak untuk membunuh itu dilakukan dalam suasana batin yang tenang. Kedua, ada tenggang waktu yang cukup semenjak timbulnya kehendak sampai pelaksanaan keputusan kehendaknya itu. Mengenai kondisi yang ketiga, pelaksanaan pembunuhan itu dilakukan dalam suasana batin tenang. Tiga unsur/syarat dengan rencana lebih dahulu yang dikemukakan di atas adalah bersifat kumulatif dan saling berhubungan, dan menjadi suatu kebulatan yang tidak dapat terpisahkan. Sebab apabila sudah terpisah/terputus, maka sudah tidak dapat lagi dikatakan dengan rencana terlebih dahulu. 
Sebagaimana yang sudah dijelaskan sebelumnya dalam latar belakang permasalahan di atas, penelitian ini dilakukan dengan tujuan mengungkap bagaimana pengaturan hukum tentang tindak pidana pembunuhan berencana serta bagaimana pertimbangan hakim dalam menjatuhkan sanksi pidana terhadap pelaku tindak pidana pembunuhan berencana studi kasus Putusan Nomor 1474/Pid.B/2019/PN.Dps.

\section{METODE PENELITIAN}

Metode penelitian yang dipakai untuk memecahkan permasalahan di atas yaitu melalui tipe penelitian dan pendekatan penelitian hukum normatif yang menempatkan hukum sebagai sebuah bangunan sistem norma. Yang dimaksud di sini ialah mengenai asas-asas, norma, kaidah dari peraturan perundangan, putusan pengadilan, serta pendapat para sarjana.

Sumber bahan hukum dalam penelitian ini adalah sumber bahan hukum primer dan sekunder. Teknik pengumpulan bahan hukum menggunakan teknik studi pencatatan dan studi dokumentasi. Bahan hukum yang sudah terkumpul kemudian diolah dan dianalisa secara deskritif dan disajikan menggunakan metode informal.

\section{HASIL PENELITIAN DAN PEMBAHASAN}

\section{Pengaturan Hukum tentang Tindak Pidana Pembunuhan Berencana}

Pengaturan mengenai Tindak Pidana Pembunuhan Berencana diatur dalam kitab undang-undang hukum pidana. Pembunuhan berencana ialah Pembunuhan dengan rencana lebih dahulu dengan ancaman pidana yang terberat dari beberapa jenis kejahatan terhadap nyawa manusia yang diatur dalam kitab undang-undang hukum pidana.

Unsur dalam konteks tindak pidana pembunuhan dengan berencana terdiri dari 2 (dua) macam, yaitu:

a) Unsur Subyektif

1) Dengan sengaja;

2) Dan dengan dipikirkan (rencana) terlebih dahulu;

b) Unsur Obyektif

1) Perbuatan menghilangkan nyawa;

2) Obyeknya nyawa orang lain.

Unsur 340 dalam KUHP dijabarkan dengan mengulang kembali isi seluruh unsur dalam pasal 338 KUHP, dan ditambah dengan satu unsur dengan rencana terlebih dahulu. Karena dalam pasal 340 KUHP mengulang seluruh unsur pasal 338 KUHP, jadi dapat disimpulkan pembunuhan berencana dianggap sebagai pembunuhan yang berbeda dan lain dengan pembunuhan biasa atau bentuk pokok (338) (Chazawi, 2007).

Pengertian direncanakan terlebih dahulu (voorbedachte raad) menurut Prof. Simons berpendapat sebagai berikut.

Orang hanya bisa berbicara tentang mengenai perencanaan lebih dahulu, bila buat melakukan sesuatu tindak pidana itu dimana pelaku sudah menyusun keputusannya dengan mempertimbangkannya secara tenang, demikian juga sudah mempertimbangkan mengenai kemungkinan- kemungkinan mengenai dampak berdasarkan tindakannya. Antara saat seorang pelaku menyusun rencananya dengan waktu pelaksanaan dari rencana tersebut selalu harus terdapat suatu jangka waktu tertentu, dalam hal seorang pelaku dengan segera melaksanakan apa yang dia maksud untuk dilakukan kiranya sulit untuk berbicara tentang adanya suatu perencanaan lebih dahulu (Lamintang \& Lamintang, 2018).

Mengenai unsur dengan rencana terlebih dahulu, pada dasarnya mengandung 3 syarat yaitu

1. Memutuskan kehendak pada suasana tenang.

2. Tersedia waktu yang cukup sejak timbulnya kehendak sampai dengan pelaksanaan kehendak.

3. Pelaksanaan kehendak pada suasana tenang.

Unsur dari dengan rencana terlebih dahulu, terbentuknya syarat pertama dan syarat kedua, dalam sudut pandang hukum pidana (Pasal 340) sepanjang kehendak dengan berencana itu belum diwujudkan dalam pelaksanaannya hal ini hanya dianggap membuktikan adanya rencana. Dalam hal ini syarat ketiga dipandang terpenting yaitu sebagai syarat untuk membuktikan telah terjadinya pembunuhan berencana. 


\section{Pertimbangan Hakim dalam Menjatuhkan Sanksi Pidana terhadap Pelaku Tindak Pidana Pembunuhan Berencana Studi Kasus Putusan Nomor 1474/Pid.B/2019/PN.Dps}

Ketentuan Undang-Undang No.48 Tahun 2009 mengenai Kekuasaan Kehakiman, dalam pasal 50 menentukan bahwa segala putusan pengadilan harus memuat alasan-alasan dan dasar-dasar putusan dan mencantumkan pasal-pasal peraturan perundang-undangan tertentu yang bersangkutan dengan perkara yang diputus atau berdasarkan hukum tak tertulis maupun yurisprudensi atau doktrin hukum. Bertitik tolak dari ketentuan pasal-pasal yang dikemukakan tersebut, putusan pengadilan yang tidak cukup pertimbangan hukum, yaitu mengemukakan dasar alasan-alasan yang jelas dan terperinci berarti mengandung cacat hukum. Akibatnya, putusan yang seperti itu, dapat dibatalkan pada tingkat banding atau kasasi (Syamsudin \& Luthan, 2018).

Berdasarkan segala pertimbangan yang dijadikan alasan majelis hakim dalam menjatuhkan putusan berupa pidana terhadap terdakwa, penulis berpendapat tidaklah tepat dalam menjatuhkan hukuman pembunuhan berencana pada putusan nomor 1474/Pid.B/2019.Dps karena dimana berdasarkan fakta yang terungkap di persidangan, berdasarkan kronologis kasus, keterangan saksisaksi, keterangan terdakwa serta dihubungkan visum et repertum dan barang-barang bukti yang diajukan dipersidangan.

Hal tersebut dapat dilihat dalam posisi kasus tidak terpenuhinya unsur-unsur pasal 340 KUHP. Padahal jika dikaji dan cermati pada posisi kasus yang dimaksud dengan pembunuhan berencana menurut Memorie Van Toelichting sebagaimana dikutip oleh Adami Chazawi, dalam konteks pasal 340 KUHP Mengenai unsur dengan rencana terlebih dahulu, pada dasarnya mengandung 3 syarat yaitu:

1. Memutuskan kehendak pada suasana tenang.

2. Tersedia waktu yang cukup sejak timbulnya kehendak sampai dengan pelaksanaan kehendak.

3. Pelaksanaan kehendak dalam suasana tenang.

Yang pertama memutuskan kehendak dalam suasana tenang adalah pada saat memutuskan kehendak untuk membunuh itu dilakukan dalam suasana (batin) yang tenang. Suasana batin yang tenang tidak tergesa-gesa atau tiba-tiba, tidak dalam keadaan terpaksa dan emosi yang tinggi (Chazawi, 2007).

Syarat pertama, yaitu terdakwa Rudianto memang telah memutuskan kehendak dalam suasana tenang yang berawal dari terdakwa menemukan percakapan pribadi antara korban Halima yang merupakan istri siri terdakwa Rudianto dengan seseorang yang bernama Wawan di media sosial Facebook. Terdakwa menduga korban Halimah berselingkuh dengan Wawan dan timbul niat terdakwa ingin membunuh Wawan selingkuhan istrinya karena Wawan menyebabkan rusaknya pernikahan terdakwa dengan Halimah. Namun dalam pembunuhan tersebut dalam pelaksanaan objeknya berbeda dari apa yang dikehendaki targetnya atau niat memutuskan membunuh. Terdakwa memutuskan seketika dalam kehendak membunuh korban dimana terdakwa dalam keadaan emosi yang tinggi yang disebabkan oleh korban, dari sikap dan perkataan korban yang tidak baik yang tidak menghargai terdakwa. Dalam hal tersebut Tidak terpenuhinya dari syarat pertama rencana terlebih dahulu.

Yang kedua tenggang waktu yang cukup. Sejak timbulnya kehendak sampai pelaksanaan keputusan kehendaknya. Waktu yang cukup ini artinya harus diukur dari lamanya waktu tertentu, dimana tergantung keadaan dan/atau kejadian konkret yang berlaku. Dalam tenggang waktu itu masih tampak adanya hubungan antara pengambilan putusan kehendak dengan pelaksanaan pembunuhan.

Syarat kedua, adanya cukup waktu, dalam tenggang waktu mana ada kesempatan untuk memikirkan dengan tenang untung ruginya pembunuhan itu dilaksanakan Dimana terdakwa membeli dan mempersiapkan pisau di pasar kembang Surabaya Jawa Timur yang dimodifikasi seperti mata tombak di kedua sisinya tajam untuk digunakan dalam mempersiapkan untuk membunuh wawan. Setelah itu terdakwa berangkat mengendarai motor dari Surabaya menuju Bali untuk bertemu dengan Halimah. Dalam kasus ini, dimana syarat kedua ada tersedia waktu yang cukup sejak timbulnya kehendak sampai dengan pelaksanaan kehendak menjadi tidak terpenuhi karena perbuatan yang ingin dikehendaki membunuh Wawan tidak terlaksana atau berubah seketika membunuh Halima. Sebaiknya, kehendak lain terjadi dikarenakan korban tidak menghargai terdakwa dari sikap dan perkataan korban ke terdakwa yang menyebabkan terdakwa emosi tinggi dan langsung mengambil 
keputusan membunuh Halima karena faktor emosi yang tinggi yang tidak bisa memikir dengan tenang lagi mempertimbangkan segala hal lagi.

Syarat ketiga, berupa pelaksanaan pembunuhan yang dilakukan dalam suasana (batin) yang tenang, hal ini merupakan syarat terpenting. Suasana hati pada saat melaksanakan pembunuhan tidak dalam suasana tergesa-gesa, amarah yang tinggi, rasa takut yang berlebihan dan lain sebagainya.

Syarat ketiga ada rencana terlebih dahulu sebagaimana yang diterangkan di atas, memiliki bersifat kumulatif dimana saling berhubungan, sebagai suatu komponen yang tak dapat terpisahkan. Sebab apabila terputus, maka rencana terlebih dahulu tidak lagi (Chazawi, 2007).

Syarat ketiga tidak terpenuhi, dimana Setelah ketemu korban halimah (istrinya) Terdakwa menanyakan "dimana kosnya?" dijawab oleh korban Halima "Mana uangnya?" kemudian Terdakwa mengambil dompet dan dompet tersebut langsung ditarik dan diambil dari tangan Terdakwa oleh korban Halima, kemudian uang dalam dompet diambil sebanyak Rp.1.700.000,- kemudian dompet dikembalikan ke Terdakwa, dan kemudian Halima (korban) berkata sudah lah kamu pulang jangan urusin saya setelah itu Rudianto mengatakan "jangan begitu kamu, saya cuman tanya dimana tempat kos kamu sekarang, kalau sudah punya suami bilang terus terang" dijawab oleh korban Halima "suami suami matamu", dan terdakwa menunjukan percakapan istrinya dengan selingkuhanya (wawan). Terdakwa menanyakan "dimana Wawan?" Namun korban Halima diam saja tidak menjawab pertanyaannya terdakwa, tetapi halima malah emosi menyuruh terdakwa dengan berkata "sudah pulang kamu enggak usah ngurus saya" istrinya (korban) menjawab dengan perkataan tidak baik. Kemudian terjadi percakapan antara terdakwa dan korban yang menjadi pemicu emosi terdakwa. Terdakwa langsung mengambil pisau di bawah jok sepeda motor yang sebenarnya mau digunakan untuk membunuh wawan. Kemudian terdakwa menusukkannya berkali-kali ke dada, perut dan punggung Halimah hingga meninggal dunia dan terakhir menendang kepala korban.

Dari posisi kasus di mana korban menunjukan sikap dan perkataan yang kurang baik terhadap terdakwa yang tidak menghargai terdakwa sama sekali yang membuat terdakwa emosi tinggi sampai memutuskan kehendak lain yang direncanakan dari semula yaitu ingin membunuh wawan. Karena sikap dan perkataan korban tersebut terdakwa malah membunuh istrinya sendiri. Sehingga objek yang direncanakan menjadi tidak terlaksana melainkan dalam pelaksanaannya membunuh objek yang berbeda apa yang dikehendaki. Di mana terdakwa dalam pelaksanaan membunuh korban dalam suasana batin yang tidak tenang dalam suasana emosional tinggi dan perbuatan membunuh itu dilakukan dengan memutuskan pelaksanaan seketika itu membunuh halimah tidak ada waktu mempertimbangan baik buruknya dalam melaksanakan pembunuhan tersebut. Jadi dalam syarat ketiga juga tidak terpenuhi. Di mana dalam pembunuhan tersebut dengan rencana terlebih dahulu sudah tidak ada lagi karena objek yang direncanakan semula tidak terlaksana melainkan pelaksanaan pembunuhan tersebut objeknya berbeda dan dilakukan seketika karena faktor emosi yang tinggi yang menyebabkan memutuskan membunuh Halimah karena Halimah tidak menghargai terdakwa dari sikap dan perkataan Halimah yang tidak baik. Jadi berdasarkan dari syarat unsur dengan rencana terlebih dahulu pasal 340 KUHP tidak terpenuhi semuanya, karena terdakwa melakukan pembunuhan tersebut dengan keadaan batin emosi tinggi dan obyek yang dikehendaki atau yang ingin dibunuh tidak terlaksana melainkan timbulnya kehendak lain karena sikap dan perkataan istri korban yang tidak menghargai terdakwa, hal tersebut membuat terdakwa memutuskan kehendak membunuh seketika korban.

Dilihat pada keterangan para saksi, seharusnya belum cukup dijadikan dasar pertimbangan karena dari fakta-fakta di atas yaitu keterangan saksi-saksi yang bersesuaian hanyalah mengenai terjadinya pembunuhan. Namun tentang pembunuhan itu dilakukan dengan rencana terlebih dahulu tidak dapat dibuktikan, sehingga menurut pendapat penulis seharusnya tidak dapat dijadikan pertimbangan.

Berdasarkan fakta yang terungkap di persidangan, berdasarkan keterangan terdakwa, keterangan saksi serta dihubungkan visum et repertum dan barang- barang bukti yang diajukan dipersidangan, bahwa terdakwa memang benar melakukan pembunuhan dengan cara menusuk korban dengan sebuah pisau yang dapat dibuktikan dengan bukti visum et repertum sebanyak 14 kali. Jika pembunuhan itu dilakukan dalam suasana tenang, terdakwa tidak melakukan penusukan berkali-kali terhadap korban. Hal itu menunjukan terdakwa emosi tinggi tidak bisa mengontrol dirinya. pada keterangan saksi dan terdakwa menyatakan terdakwa setelah menusuk korban berkali-kali hingga roboh kemudian membuang pisau tersebut dan terdakwa memindahkan motornya sekitar 10 meter 
kemudian terdakwa kembali ketempat Halima dan menendang kepala korban satu kali yang dalam posisi tengkurap di tanah. Disana terlihat terdakwa masih emosi tinggi dengan korban. Dengan melihat secara keseluruhan dari fakta-fakta di persidangan dari posisi kasus, keterangan terdakwa, keterangan para saksi, keterangan ahli berdasarkan visum et repertum dan alat-alat bukti di persidangan.

Majelis hakim menjatuhkan pembunuhan berencana pasal 340 KUHP. Berdasarkan fakta-fakta diatas hakim salah menerapkan hukuman terhadap terdakwa. Hakim kurang teliti, cermat dalam menafsirkan isi pasal yang tepat dalam menjatuhkan hukuman terhadap terdakwa. Berdasarkan faktafakta di persidangan, hukuman yang tepat atau sepadan dengan tindakan yang dilakukan oleh terdakwa dari peraturan perundang-undangan terkait adalah sebagai pembunuhan biasa pasal 338 KUHP bukan pembunuhan berencana pasal 340 KUHP.

Berdasarkan fakta-fakta di persidangan dalam kasus pembunuhan tersebut obyek yang dibunuh bukan lagi yang direncanakan semula ingin dibunuh, melainkan kehendak lain karena emosi yang disebabkan oleh korban dari sikap dan perkataan korban yang tidak baik yang tidak menghargai terdakwa sama sekali yang membuat terdakwa emosi dan dilakukan dengan keputusan seketika membunuh korban. Jadi dari unsur pasal 340 KUHP dengan rencana terlebih dahulu pada dasarnya mengandung 3 syarat dan dalam syarat tersebut menurut penulis berpendapat tidak terpenuhi sama sekali pembunuhan tersebut digolongkan lagi pembunuhan berencana. Jadi, dalam putusan hakim tidak tepat terdakwa dijatuhi hukuman pembunuhan berencana pasal 340 KUHP dan menurut penulis pada kasus pembunuhan tersebut seharusnya dijatuhi hukuman pembunuhan biasa pasal 338 KUHP.

\section{SIMPULAN DAN SARAN}

\section{Simpulan}

Berdasarkan hasil dan pembahasan di atas, ada beberapa simpulan yang dapat dibuat, yaitu:pertama, pengaturan tentang pembunuhan berencana diatur dalam pasal 340 kitab undang-undang hukum pidana. Selain itu, pertimbangan hakim dalam menjatuhkan sanksi pidana terhadap pelaku tindak pidana pembunuhan berencana pada putusan nomor 1474/Pid.B/2019.PN.DPS yaitu majelis hakim dalam menjatuhkan putusan terhadap terdakwa berdasarkan fakta yang terungkap di persidangan, keterangan dari saksi-saksi, keterangan dari terdakwa serta dihubungkan visum et repertum dan barang-barang bukti yang ada diajukan di dalam persidangan. Pemerintah khususnya lembaga yudikatif disarankan mengawasi, membina proses peradilan dalam menerapkan hukuman.

\section{Saran}

Ada juga beberapa saran yang perlu disampaikan berdasarkan hasil dan pembahasan penelitian ini, yaitu: pertama, hakim harus memperhatikan dan menyusun pertimbangan sehingga hakim dalam membuat putusan, memuat dasar, dan alasan-alasan yang jelas serta terperinci agar setiap putusan memenuhi ketentuan peraturan perundang- undangan terkait. Kedua, pemerintah khususnya lembaga yudikatif harus mengawasi dan membina proses peradilan terutama hakim agar setiap putusanya tidak menjadi keputusan yang kontroversial yang tidak salah dalam menerapkan hukuman terhadap terdakwa.

\section{DAFTAR PUSTAKA}

Adonara, F. F. (2015). Prinsip Kebebasan Hakim dalam Memutus Perkara Sebagai Amanat Konstitusi. Jurnal Konstitusi, 12(2), 217-236.

Ante, S. (2013). Pembuktian dan Putusan Pengadilan dalam Acara Pidana. Lex Crimen, 2(2), 98-104.

Chazawi, A. (2007). Kejahatan terhadap Tubuh \& Nyawa. Jakarta: Raja Grafindo Persada.

Chazawi, A. (2013). Kejahatan terhadap Tubuh \& Nyawa (6th ed.). Jakarta: Raja Grafindo Persada.

Ekatjahjana, W. (2015). Negara Hukum, Konstitusi, dan Demokrasi. Jember: Jember University Press.

Lamintang, P. A. F., \& Lamintang, T. (2018). Delik-Delik Khusus Kejahatan terhadap Nyawa, Tubuh, dan Kesehatan. Jakarta: Sinar Grafika.

Nugroho, B. (2017). Peranan Alat Bukti dalam Perkara Pidana dalam Putusan Hakim Menurut KUHAP. Yuridika, 32(1), 17.

Sagama, S. (2016). Analisis Konsep Keadilan, Kepastian Hukum dan Kemanfaatan dalam Pengelolaan Lingkungan. Mazahib, 15(1), 20-41.

Sardol, S. M. (2014). Pengaturan Hak Asasi Manusia dalam Hukum Indonesia. Rechtsidee, 1(1).

Syamsudin, M., \& Luthan, S. (2018). Mahir Menulis Studi Kasus Hukum (SKH). Jakarta: Prenadamedia Group. 